\title{
The Nonlinear Relationship between Banks Competition and Financial Stability in China
}

\author{
Shehong $\mathrm{Hou}^{1}$ \\ ${ }^{1}$ School of business, Shanghai DianJi University, Shanghai, China \\ Correspondence: Shehong Hou, School of business, Shanghai DianJi University, Shanghai, China. E-mail: \\ 59801221@qq.com
}

Received: June 15, 2021

Accepted: July 27, 2021

Online Published: July 31, 2021

doi:10.5539/ijef.v13n9p33

URL: https://doi.org/10.5539/ijef.v13n9p33

\begin{abstract}
For the deeply impacts of China's banks stability on itself and world economy, we use dynamic GMM method to investigate the nonlinear relationship between banks competition and their stability. When competition is lower than certain level, the "competition-stability" comes into existence, otherwise "competition-fragility" holds on. The stock market disaster in 2015 does not have significant influence on the z-scores of banks, but it caused the non-performance loans increase evidently. The separate supervision and separate operation of financial industry may be the main reasons for the above results. China should take some actions to maintain appropriate competition for the stability of its banks system.
\end{abstract}

Keywords: dynamic GMM regression, optimal banks competition level, policy implications

\section{Introduction}

Since formally joined WTO in 2006, China has loosen the market entry requirements substantially which encouraged the establishment of many new domestic and foreign banks, and the competition in the banking system dramatically rises and led to a strong increase of banks risk. For the heavily damage of the 2008 global financial crisis, financial stability became the focus of policy concern. The bankruptcy of Bao-shang Bank Limited alarmed the market to concern the stability of China's banks. As the world largest banking system (Note 1), the stability of China's banking system is not only important for the steady operation of China's economy, but also for the stability of world economy and finance.

There are three types of relationship between the banks competition and stability; they are respectively competition leads to stability, or fragility or a non-linear linkage. The last one means there is an optimal competition level for the stability of banks. Greater concentration and exclusive monopoly fosters financial fragility, but lower pricing power also induces bank risk exposure. Which type of relationship is most suitable has been a focus of academic and policy debate. Should banks price much higher than marginal cost, to earn higher profits, to increase capital ratios and other safety financial buffers, to bolster their resilience; or should they reduce their market power, for example, higher rates and fees prevent borrowers and consumers from more risk. This is not a trifling for banking regulators.

This paper aims to investigate the influence of competition on banks stability in China. We expected there might be an optimal level of banks competition for china's banks stability. Unconstrained openness and fierce competition will lead to under capitalization and insufficient margins and profits, which is the important causes of bank failure recently. While insufficient competitive banking system tends to charge higher loan rates, increasing the burden for borrowers repay. The public guarantees or subsidies for big banks may cause them take more risky behavior and damage financial stability.

We test the linear and non-linear relationships between banks competition and their stability or risk, measured in Z-scores and the non-performing loans. The former index describes how well the banks distributing their returns, which is related to the probability that a bank's losses exceed its capital. The Lerner index is used to measure the competition degree, which is computed as the difference of price and banks 'marginal cost dividend by the price. The more the Lerner value, the less competition in banks system. Deregulation and excessive competition led to financial sector meltdown in the UK and US. Whether the relationship between bank competition and financial stability has been affected after the 2015 equity disaster in China? We use a dummy variable of macro financial 
environment to identify its influence.

The paper is organized as following. Section 2 provides the theory and review of literature on banks competition and stability. Section 3 introduce econometric methodology and explain the empirical results. Section 4 is robust checks and discussion and we conclude in Section 5.

\section{Theory Basis and Literature Review}

There mainly two hypothesis about the competition and banks stability, one is "competition-stability", the other is that "competition-fragility". This sector will provide the mechanism of competition influence the stability of banks theoretically and the related empirical studies.

\subsection{The Theory about Banks Competition and Stability}

Competition-stability: banks with more market power can increase their interest rates from originating riskier loans in greater amounts. Fu et al. (2013) tend to charge higher loan rates, which induce borrowers to assume greater risk and leading to greater default and finally threatens the stability of the banking system. In a concentrated banking system, policymakers are more concerned about bank failures (Mishkin, 1999, 2006), large banks are often more likely to receive public guarantees or subsidies, which may generate a moral hazard problem, encourage risk-taking behavior and intensify financial fragility.

Competition-fragility: a more competition or less centralized banking system increase instability. Fierce competition makes banks to engage in riskier activities for higher returns, they are reluctant to provide liquidity to their vulnerable counterparts, to support interbank cooperation and assistance. Banks with more monopoly have higher franchise value; this may prevent excessive risky decisions of the bank's executives. The higher value of Franchise, the higher opportunity cost of bankruptcy, leading to less dangerous decisions, thereby improving the quality of bank assets (Nguyen, Le, \& Tran, 2017).

Banks competition and stability may also related in a non-linear manner. Banks with more market power can charge higher loan rates, which induce borrowers to assume greater risk, thus threaten the stability of banks (Boyd \& De Nicholo, 2005). Higher loan rates also bring banks higher interest revenues. Competition and concentration may coexist and simultaneously induce stability or fragility. These opposite impacts might generate a $\mathrm{U}$-shaped relationship between banks competition and stability.

Recently, with the rapid step of financial openness, fierce competition has caused a few banks failure, such as the bankruptcy of Bao-shang bank. To find which paradigm between competition and stability prevailing in china.

\subsection{Related Empirical Studies}

Competition-fragility paradigm is supported in Latin American and Asian banking systems (Yeyati \& Micco, 2007; Liu et al., 2013; Fu et al., 2014),which is also suitable for Western European and US Banks (Schaeck \& Cihak, 2014). Keeley (1990) find that increased competition and deregulation in US banking system leading to bank failures during 1990s.Berger et al. (2009) find that concentrated banking system will expose to less overall risks. Bank level market power can result in riskier loan portfolio, can protect banks' charter value by holding more equity capital. Jimenez et al. (2007) show that the greater competition in banking system, the higher risk of the loan portfolio such as more non-performing loans. Hellmann et al. (2000) show that removing the interest rate ceiling will increase the price competition between banks, and reduce the franchise value, thereby cause more moral hazard behavior. Vives (2010) argue that competition could aggravate instability issues.

There are also studies support the view of competition-stability, larger banks may receive guarantees and grant from government, which will induce moral hazard problem, they are more likely to take dangerous decisions and threaten the stability of banking system (Mishkin, 1999). Schaech and Cihak (2014) find that competition increases efficiency and the soundness of banking system with sample banks from European and US between 1995 to 2005 . Schaeck et al.(2008) ${ }^{[14]}$ show that after controlling for the banks concentration, competition can reduce the likelihood of a crisis and increase stability. Angier et al. (2012) use Lerner index and default risk under Merton (1974) contingent claim pricing framework to examine the impact of competition on banks stability, and find a positive relationship between them. Caminal et al. (2002) argue that insufficient competition causes easier credit granting and larger loans, which increases the likelihood of bank failure. Beck et al. (2006) find that with high competition are less likely to suffer financial crisis. Boyd et al. (2005)argue banks with greater market power or less competition charge higher loan rates, which increase the difficulty for customers to repay, eventually threaten their stability.

\section{Econometric Method}

To determine the effects of competition on banks' risk taking, we process a two-stage econometric model. Firstly, 
we estimate the Lerner index, which measures the competition of banking system. To measure bank risk, we use the Z-score and the non-performing loan to measure bank risk. Secondly, we investigate the relationship between competition and banks' risk-taking.

We uses data from 22 commercial banks in China, which is composed of four large state-owned banks, ten Joint-stock Commercial Banks and eight foreign-funded commercial banks, for the period 2008-2016. Generalized Method of Moments (GMM) estimator was used to overcome the potential endogenous problem.

\subsection{The measurement of Banks' Stability}

Z-score is the most widely used accounting-based index to measure commercial banks risk (Boyd, 1993). When equity is insufficient to offset losses, i.e. $E<-\widetilde{\pi}$, bankruptcy will take place. Letting $\mathrm{A}=$ total assets, the return rate is $\widetilde{r}=\frac{\widetilde{\pi}}{A}$, and $k=\frac{-E}{A}$, then the probability of bankruptcy is

$$
p(E<-\pi)=p(\widetilde{r}<k)=\int_{-\infty}^{k} \phi(r) \mathrm{d} r
$$

Where $p($.$) is a probability and \phi(r)$ is the p.d.f of $r$. If $\widetilde{r}$ is normally distributed, (1) can be rewritten as

$$
\begin{aligned}
& p(\widetilde{r}<k)=\int_{-\infty}^{z} N(0,1) \mathrm{d} z \\
& z=\frac{k-\rho}{\sigma}
\end{aligned}
$$

Where $\rho$ is the true mean and $\sigma$ is the true standard deviation of the $r$ distribution. And $\mathrm{z}$ is the number of equity is less than the mean loss. The accounting data Z-score is

$$
Z_{i t}=\frac{R O A_{i t}+E_{i t} / T A_{i t}}{\sigma_{R O A_{i p}}}
$$

Here $R O A$ is the return on assets, E/TA is the equity to total assets ratio, and $\sigma_{R O A}$ is the standard deviation of return on assets.

The Z-score and the probability of a bank's bankruptcy is negatively related. When its asset value drops below its debt, a bank becomes insolvent and the Z-score shows the number of standard deviations that a bank's return has to fall below its expected value to deplete equity and make the bank insolvent.

\subsection{The Measurement of Banks' Competition}

We use Lerner index, which is the mark-up of price over a bank's marginal cost, to measure the market power of banks.

$$
\text { Lerner }_{i t}=\frac{p_{i t}-\frac{\partial c_{i t}}{\partial y_{i t}}}{p_{i t}}
$$

Where $p_{i t}$ is the average price of bank i's output at time $t$, calculated by the ratio of total income to total assets. $c_{i t}$ is the bank's total cost and $y_{i t}$ is its output. Banks market are perfect competition when Lerner $_{i t}=0$, and the competition increased as the Lerner ${ }_{i t}$ 's value increases.

The main task for econometric is to estimate the marginal cost of banks $\partial c_{i t} / \partial y_{i}$, which is estimated from the banks total cost function (Fu et al., 2013).

$$
\begin{aligned}
\ln c_{i t} & =\alpha_{0}+\sum_{j=1}^{3} \alpha_{j} w_{i t}^{j}+\frac{1}{2} \sum_{j=1}^{3} \sum_{k=1}^{3} \alpha_{j k} \ln w_{i t}^{j} \ln w_{i t}^{k}+\beta_{1} \ln y_{i t}+\frac{1}{2} \beta_{2}\left(\ln y_{i t}\right)^{2} \\
& +\sum_{j=1}^{3} \beta_{j}^{\prime} \ln y_{i t} \ln w_{i t}^{j}+\psi_{1 t} \times T+\frac{1}{2} \psi_{2 t} \times T^{2} \sum_{j=1}^{3} \psi_{3 t} \times T \ln w_{i t}^{j}+\psi_{4 t} \times T \ln y_{i t}+\mu_{t}+\epsilon_{i t}
\end{aligned}
$$

$c_{i t}$ is the total costs of the bank $\mathrm{i}$ at the year $\mathrm{t}$ and is equal to the sum of interest expenses, commission and fee expenses, trading expenses, personnel expenses, administrative expenses, and other operating expenses, measured in RMBs. $y_{i t}$ is the quantity of output and is measured as total assets in RMBs. $w_{k, i t}$ are the prices of inputs. $w_{1, i t}$ is the ratio of interest expenses to total assets. $w_{2, i t}$ is the ratio of personnel expenses to total assets $w_{3, i t}$ is the ratio of administrative and other operating expenses to total assets. $T$ is the time trend reflecting the effect of technical progress, $\mu$ captures the individual fixed effects, and $\epsilon_{i t}$ is the error term.

We use the method of fixed effects with robust standard error to estimate banks total cost function, and get the 
coefficients for marginal cost in (6)

$$
M C_{i t}=\frac{c_{i t}}{y_{i t}}\left(\beta_{1}+\beta_{2} \ln y_{i t}+\sum_{j=1}^{3} \beta_{j}^{\prime} \ln w_{i t}^{j}+\psi_{4 t} T\right)
$$

Which is the derivative of total cost function with output in equation (5).When the values of prices and marginal costs of banks' output have gotten, we can work out the Lerner indexes as equation (4).

\subsection{The Empirical Models}

We can estimate the following two equation to find the linkage between competition and banks stability in China. The first one is a dynamic model proposed by Fernandez et al. (2015), which includes the latency of the dependent variable as an independent variable. We only consider the first latency for the relative small sample.

$$
\begin{gathered}
\ln \left(z_{i t}\right)=\alpha_{i t}+\delta \ln \left(z_{i, t-1}\right)+\beta_{1} \text { Lerner }_{i t}+\beta_{2}\left(\text { Lerner }_{i t}\right)^{2} \\
+\beta_{3} \text { Size }_{i t}+\beta_{4} \text { Loanta }_{i t}+\epsilon_{i t} \\
N P L_{i t}=\alpha_{i t}+\delta N P L_{i, t-1}+\beta_{1} \text { Lerner }_{i t}+\beta_{2} \text { Lerner }_{i t}^{2}+ \\
\beta_{3} \text { Banksize }_{i t}+\beta_{4} \text { Loanta }_{i t}+\epsilon_{i t}
\end{gathered}
$$

$\ln \left(z_{i l}\right)$ is the natural logarithm of Z-score which measures the stability, and NPL (non-performing loan) presents banks' risk. Lerner index delegates the competition level of banks market. The square of Lerner index is used to measure the non-linear relationship between competition and stability. We add some bank specific variables in the model such as Banksize measured by the logarithm of total assets, the ratio of total loans to total assets (Loanta), and the own dummy variable which takes the value of one, when the bank is capitalized by foreign fund, otherwise zero. In order to find the impact of equity disaster in 2015 on china's banks, we define the disaster year 2015 as one. Then the model take the forms as

$$
\begin{aligned}
\ln \left(z_{i t}\right)= & \alpha_{i t}+\delta \ln \left(z_{i, t-1}\right)+\beta_{1} \text { Lerner }_{i t}+\beta_{2}\left(\text { Lerner }_{i t}\right)^{2}+\beta_{3} \text { Crisis }_{i t} \\
& +\beta_{4} \text { Banksize }_{i t}+\beta_{5} \text { Loanta }_{i t}+\epsilon_{i t} \\
N P L_{i t} & =\alpha_{i t}+\delta N P L_{i, t-1}+\beta_{1} \text { Lerner }_{i t}+\beta_{2} \text { Lerner }_{i t}^{2}+\beta_{3} \text { Crisis }_{t} \\
& +\beta_{4} \text { Banksize }_{i t}+\beta_{5} \text { Loanta }_{i t}+\epsilon_{i t}
\end{aligned}
$$

And we can use the Lerner index times the dummy variable of equity disaster to test the dual influences of them on banks stability.

$$
\begin{aligned}
\ln \left(z_{i t}\right)= & \alpha_{i t}+\delta \ln \left(z_{i, t-1}\right)+\beta_{1} \text { Lerner }_{i t}+\beta_{2}\left(\text { Lerner }_{i t}\right) \times \text { crisis }_{i t}+\beta_{3} \text { Banksize }_{i t} \\
& +\beta_{4} \text { Loanta }_{i t}+\epsilon_{i t} \\
N P L_{i t} & =\alpha_{i t}+\delta N P L_{i, t-1}+\beta_{1} \text { Lerner }_{i t}+\beta_{2} \text { Lerner }_{i t} \times \text { Crisis }_{i t}+\beta_{3} \text { Banksize }_{t} \\
& +\beta_{4} \text { Loanto }_{i t}+\epsilon_{i t}
\end{aligned}
$$

For the non-strict, exogenous of independent variables which may correlated with past and current realizations of the error; fixed effects; heteroscedasticity and autocorrelation

within individuals, the linear estimate methods of panel data such as FE (fixed effects), RE (random effects), LSDV (least squares dummy variable) are no longer suitable. The panel of 10 years and 22 individuals means "small T, large N", so Difference GMM (DGMM) method proposed by Arellano and Bond (1991) for dynamic panel is used in our research.

\section{Research Data and Empirical Results}

We first define the dependent and independent variables and present the research data, then present the empirical results for the banking market in China.

\subsection{Variable Definition and Descriptive Statistics}

The sample data focus on 22 commercial banks in China for the period from 2010 to 2019, which include 220 observations. Accounting annually data for individual banks are obtained from CSMAR database in RMB. 
Table 1. Variable definition and descriptive statistics

\begin{tabular}{|c|c|c|c|c|c|}
\hline variables & definition & mean & $\min$ & $\max$ & std \\
\hline $\ln \left(z_{i l}\right)$ & The logarithm of Z-score, $\ln \frac{R O A_{i t}+E_{i t} / T A_{i t}}{\sigma_{R O A_{i p}}}$ & 1.9705 & 0.6331 & 2.6484 & 0.4103 \\
\hline NPL & $\frac{\text { Non }- \text { performanceloans }}{\text { Total loans }}$ & 0.0023 & 0.0002 & 0.0060 & 0.0014 \\
\hline Lerner & $\frac{P_{i t}-M C_{i t}}{P_{i t}}$ & 0.4827 & 0.1598 & 0.8978 & 0.1831 \\
\hline Banksize & $\ln ($ Total assets $)$ & 27.5481 & 22.6518 & 31.0559 & 2.4523 \\
\hline Loanta & 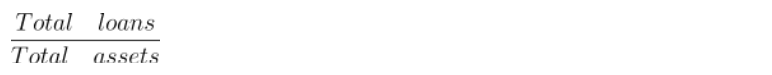 & 0.4904 & 0.2640 & 0.7912 & 0.0854 \\
\hline $\begin{array}{l}\text { Stock market } \\
\text { disaster }\end{array}$ & $\begin{array}{l}\text { Dummy variable for stock market disaster in } 2015 \text {, value }=1 \text {, when } \\
\text { the year is } 2015 \text {, in the remain years, the values equal } 0\end{array}$ & 0.1 & 0 & 1 & 0.3007 \\
\hline
\end{tabular}

Source: computing results from Eviews 10.

From table 1 , we can see the average $\ln \left(z_{\text {score }}\right)$ of the sample banks is 1.9705 , the most stable bank has a $\ln \left(z_{\text {score }}\right)$ of 2.6484 , such value of the lowest stability bank is 0.6331 . The average Lerner index of our sample is 0.4827, indicating that there has a relatively high level of monopoly in the banking market in China. As the foreign fund banks, the non-performance loan is incomplete, the data of NPL only including 14 Chinese fund banks.

\subsection{The Relationship between Bank Competition and Stability}

We use Dynamic GMM method to regress equations (7) to (12), in which Z_score and NPL are the dependent variables to stand for banks' stability and fragility. For each dependent variables we first consider the impact of competition, then the impact of equity disaster, the last is the impact of competition under the condition of equity disaster on the stability of china's banks.

Table 2. Banks competition and stability measured in $z_{\text {score }}$

\begin{tabular}{|c|c|c|c|}
\hline Dependent variable & & Ln(z-score) & \\
\hline model & (7) & (9) & (11) \\
\hline $\ln \left(z_{\text {score }}\right)_{-1}$ & $0.2721^{* * *}(0.0463)$ & $0.3300^{* * *}(0.0463)$ & $0.2643^{* * *}(0.0380)$ \\
\hline Lerner & $-0.4742^{* * *}(0.1271)$ & $-0.4283^{*}(0.2468)$ & $-0.0385(0.0313)$ \\
\hline Lerner ${ }^{2}$ & $0.4823^{* * *}(0.1174)$ & $0.4478^{*}(0.2518)$ & \\
\hline Bank size & $0.0789^{* * *}(0.0152)$ & $0.0575^{* *}(0.0225)$ & $0.0924^{* * *}(0.0263)$ \\
\hline Loanta & $1.3913^{* * *}(0.0751)$ & $1.4136^{* * *}(0.0975)$ & $1.4274^{* * *}(0.1073)$ \\
\hline Stock disaster & & $0.0090(0.0099)$ & \\
\hline Lerner $\times$ disaster & & & $-0.0058(0.0277)$ \\
\hline Hanson p-value & 0.3205 & 0.3303 & 0.3684 \\
\hline P-value of AR(1) & 0.6552 & 0.8808 & 0.7365 \\
\hline
\end{tabular}

Source: calculating results from Eviews 10.

Table 2 shows the results of DGMM panel data estimations where the dependent variable is the natural logarithm

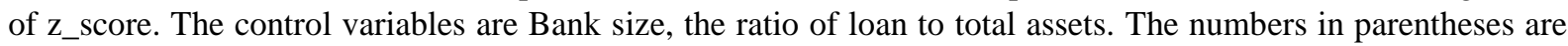
the standard errors of the coefficients.

$* * *, * *$ and $*$ Indicate significance at the $1 \%, 5 \%$ and $10 \%$ level respectively. The coefficient without stars means not significant.

When the dependent variable is Z-score, the p-value of the three models are all excess than $10 \%$ level, which means there are no first order in the residuals, the same is true for higher orders. P-values of Hanson test in the six models are all greater than 5\%, which indicate the instrument variables of the models are suitable. For the NPL model, table 3 shows that all three models have a p-value of AR (1) test less than 5\% and a p-value of AR (2) greater than level of $5 \%$. Therefore, the residual has a first ordered correlation but no second ordered correlation. In the same time, the Hanson test has a p-value greater than 5\%, so the instrument variables of the models are proper. 
The coefficients of Lerner and Lerner ${ }^{2}$ in equations (7) and (9) are both significant at $1 \%$ level, and the former is negative and the last is positive. Specifically, the higher the lerner index, the lower the z-score, or more market power of the banks leads to instability of China's banks. This is consistent with the competition-stability hypothesis supported by Beck et al. (2006), Boyd and De Nicolo (2005) and (Berger et al., 2008) etc. The positive coefficient of Lerner $^{2}$ means there is a non-linear relationship between competition and stability. For the lerner index is proxy of monopoly, which is inverse of competition. That is to say, the relationship between the competition and stability is inversed U-shaped. There is an optimal level of competition for the stability of banks in China. When competition is below this level, the "competition-stability" hold in China, otherwise the "competition - fragility" holds on. The model in equation (9) give us the impact of equity disaster in 2015 on the stability of banks in China. We can see the regression coefficient of equity disaster is not significant, which means this event does not have significant impact on banks system stability. Model of (11) gives the impact of competition on banks stability when equity disaster happens in 2015 , the coefficient of Lerner $\times$ crisis is negative but does not significant, which means the stock market crash dose not have a direct impact on the stability of China's commercial banks system. At that time, China implemented separate supervision and separate operations in finance industry, the deposit funds in banks are prohibited from entering the stock market, ${ }^{[21]}$ but all kinds of wealth management products have participated in the stock market, so the collapse of stock market has some influences on banks.

Table 3. Banks competition and non-performance loan

\begin{tabular}{|c|c|c|c|}
\hline Dependent variable & & NPL & \\
\hline model & $(8)$ & $(10)$ & (12) \\
\hline$N L_{-1}$ & $0.5513^{* * *}(0.0802)$ & $0.4619^{* * *}(0.0769)$ & $0.5101^{* * *}(0.1208)$ \\
\hline Lerner & $-0.0142^{* * *}(0.0041)$ & $-0.0136^{* *}(0.0049)$ & $-0.0032^{* *(0.0013)}$ \\
\hline Lerner ${ }^{2}$ & $0.0136^{* * *}(0.0046)$ & $0.0152^{* * *}(0.0042)$ & \\
\hline Banksize & $0.0012^{* * *}(0.0001)$ & $0.0013^{* * *}(0.0001)$ & $0.0014^{* * *}(0.0002)$ \\
\hline Loanta & $-0.001(0.0007)$ & $-0.0003(0.0013)$ & $-0.0016(0.0020)$ \\
\hline Stock disaster & & $-0.00001(0.0003)$ & \\
\hline Lerner $\times$ disaster & & & $-0.0005^{* * *}(0.0002)$ \\
\hline Hanson p-value & 0.2363 & 0.2665 & 0.2630 \\
\hline$p$-value of $A R(1)$ & 0.0075 & 0.0193 & 0.0507 \\
\hline$p$-value of $A R(2)$ & 0.2774 & 0.5846 & 0.2595 \\
\hline
\end{tabular}

Source: computing results from Eviews 10.

Note. ${ }^{* *},{ }^{* *}$ and $*$ Indicate significance at the $1 \%, 5 \%$ and $10 \%$ level respectively. The coefficient without stars means not significant. The numbers in parentheses are the standard errors of the coefficients.

For the NPL model, there is a U-shaped relationship between the banks market power measured in Lerner index and non-performance loan as shown in table 3. Specially, the coefficients of Lerner index for the three models of NPL are both negative and significant at least in 5\% level, and the coefficients of Lerner square is positive and significant at $1 \%$ level in models (8) and (10). When the banks do not have sufficient market power, the increasing of monopoly can reduce the non-performance loan, or we can say competition damage the stability of banks. The banks market power exceeds the essential level will cause nonperformance loan rising, the "competition-stability" holds on. When the competition level is lower or the banks have excessive market power, increasing competition can make them to reduce risky loans and loan interests thus lead to lower non-performing loans. While the competition level is higher than the optimal level, competition further increasing makes banks to engage in riskier activities for higher returns, such as lending to those with high probability of default, thus the non-performance loans increase and threaten the stability of the banks system.

Model (10) shows that the stock market disaster in 2015 does not have significant impact on banks' non-performance loans, though the coefficient of "stock-disaster" is very negative but not significant. Though the rapid rising of stock index has attracted huge loan funds of banks entering stock market, banks are prohibited of entering the stock market directly; the stock market crash has only limited influence on the banks. Model (12) indicates that competition in the context of stock disaster has deteriorated banks loans, for the coefficient of Lerner $\times$ disaster is significantly negative at $1 \%$ level. In the context of stock disaster environment, competition between banks will encourage more risky loans for higher return and more nonperformance loans produced. 
The coefficients of stock market disaster in talbe 2 and table 3 are both not significant, which tell us the crash of stock market does not influence the banks system in China. The separate operation and supervision of China's financial system may have helped the banks avoiding the shock of stock market crash. In the models of NPL, the ratio of non-performance loan to total loans in the last period has a significant positive influence on the current nonperformance loan ratio. Similarly, the $\ln$ (z-score) of the last period also has a positive impact on the present value, which indicates there are strong moment effects of banks stability and nonperformance loan.

\section{Conclusions}

This paper investigates the nexus between competition and stability using cross-banks data in China for the period from 2010 to 2019. The z-score and non-performance loan to total loan are used respectively to measure the stability and fragility of banks, and Lerner index was calculated to measure the competition of banks. The Dynamic GMM estimation results show that the relationship between competition and banks stability is not linear, but a U-shaped one. When the competition not exceeding the optimal level, the hypothesis of "competition-stability" holds on; and when the competition exceeds the optimal one, the "competition-fragility" hypothesis is tenable. We also find there are momentum effects on the current values of the stability and fragility of banks measured in $\ln$ (z-score) and the ratio of non-performance loan to total loans. At last, we detect that the stock market disaster in 2015 has not significant affection on the stability of banks in China. This may be due to the separate supervision and separate operation mechanism of China's finance industry.

Our finding highlights several implications for policy maker. First, maintaining a moderate competition level is essential for China's banks stability. To prevent banks excessive concentration or to increase the competition, regulators should evaluate and approve banks merger and acquisitions more cautiously. Second, reducing policy lending of the state-owned large banks is benefit for the control of non-performance loan rising. Regulators should advocate independent credit cultures in the banks greatly. Third, appropriate entry restrictions are needed for both domestic and foreign entrants to prevent excessive competition in banks market. There should be stricter scrutiny of foreign banks that seek to make acquisitions in China. Lastly, to financial innovation among banks based on the effective risk management should be encouraged, which can improve the efficiency of resource allocation within an economy and enhance the stability of the banks system.

\section{Acknowledgments}

I would like to thank my family, just their supporting help me complete the work, and I also thank my director Professor Yang jin qiang who give me much valuable suggestions and comments for the research.

\section{References}

Anginer, D., Demirguc-Kunt, A., \& Zhu, M. (2012). How Does Bank Competition Affect Systemic Stability? Policy Research Working Paper No. 5981, World Bank. https://doi.org/10.2139/ssrn.2020584

Beck, T., Demirguc-Kunt, A., \& Levine, R. (2006). Bank concentration, competition, and crises: First results. Journal of Banking and Finance, 30, 1581-1603. https://doi.org/10.1016/j.jbankfin.2005.05.010

Berger, A., Klapper, L., \& Turk-Ariss, R. (2009). Bank competition and financial stability. Journal of Financial Services Research, 35, 99-118. https://doi.org/10.1007/s10693-008-0050-7

Boyd, J. H. (1993). Bank holding company mergers with nonbank financial firms: Effects on the risk of failure. Journal of Banking and Finance, 17, 43-63. https://doi.org/10.1016/0378-4266(93)90079-S

Boyd, J. H., \& De Nicolo, G. (2005). The theory of bank risk-taking and competition revisited. Journal of Finance, 60, 1329-1343. https://doi.org/10.1111/j.1540-6261.2005.00763.x

Caminal, R., \& Matutes, C. (2002). Market power and bank failures. International Journal of Industrial Organization, 20, 1341-1361. https://doi.org/10.1016/S0167-7187 (01)00092-3

Eduardo, L. Y., \& Alejandro, M. (2007). Concentration and Foreign Penetration in Latin American Banking Sectors: Impact on Competition and Risk. Journal of Banking \& Finance, 6(31), 1633-1647. https://doi.org/10.1016/j.jbankfin.2006.11.003

Fu, X. M., Lin, Y. R., \& Molyneux, P. (2014). Bank competition and financial stability in Asia Pacific. Journal of Banking \& Finance, 38, 64-77. https://doi.org/10.1016/j.jbankfin.2013.09.012

Hellmann, T., Murdock, K., \& Stiglitz, J. (2000). Liberalization, moral hazard in banking, and prudential regulation: are capital requirements enough? American Economic Review, 90, 147-165. https://doi.org/10.2139/ssrn.92288

Hong, L., Phil, M., \& John, O. S. W. (2013). Competition and stability in European banking: A regional analysis. 
The Manchester School, 2(81), 176-201. https://doi.org/10.1111/j.1467-9957.2011.02285.x

Jimenez, G., Lopez, J., \& Saurina, J. (2007). How does Competition Impact Bank Risk Taking? Banco de Espana Working Papers, 1005. https://doi.org/10.1016/j.jfs.2013.02.004

Jingyun, D., \& Yu, X. (2005). Research on the Relationship between Commercial Banks and Enterprises in China. Chongqing Industrial and Commercial University (Social Sciences), 1(22), 44-52.

Klaus, S., \& Martin, C. (2014). Competition, Efficiency, and Stability in Banking. Financial Management, 43(1), 215-241. https://doi.org/10.1111/fima.12010

Michael, C. K. (1990). Deposit Insurance, Risk, and Market Power in Banking. American Economic Review, 5(80), 1183-1200.

Mishkin, F. S., \& Feldman, R. S. (2006). A Review of "Too Big to Fail: The Hazards of Bank Bailouts". Journal of Economic Literature, 4(44), 988-1004. https://doi.org/10.1257/jel.44.4.988

Mishkin, S. F. (1999). Financial consolidation: dangers and opportunities. Journal of Banking and Finance, (23), 675-691. https://doi.org/10.1016/S0378-4266(98)00084-3

Nguyen, T. L., Le, A. H., \& Tran, D. M. (2017). Bank Competition and Financial Stability: Empirical Evidence in Vietnam (pp. 584-596). Cham: Springer International Publishing. https://doi.org/10.1007/978-3-319-73150-6_46

Robert, C. M. (1974). Fallacy of the log-normal approximation to optimal portfolio decision-making over many periods. Journal of Financial Economics, 1(1), 67-94. https://doi.org/10.1016/0304-405X(74)90009-9

Schaeck, K., \& Cihak, M. (2008). How does competition affect efficiency and soundness in banking? New empirical evidence. Working Paper No. 932, European Central Bank. https://doi.org/10.2139/ssrn.1088605

Xavier, V. (2010). Competition and stability in banking. Iese Research Papers, 2(13), 85-112.

\section{Note}

Note 1. By the end of 2016, the total assets of the Chinese banking industry ( $\$ 33$ trillion) had surpassed the euro zone economy (\$31 trillion), the US (\$16 trillion) and Japan (\$ 7 trillion)and has been the world's largest banking system.

\section{Copyrights}

Copyright for this article is retained by the author(s), with first publication rights granted to the journal.

This is an open-access article distributed under the terms and conditions of the Creative Commons Attribution license (http://creativecommons.org/licenses/by/4.0/). 